\title{
Assessment of Biochemical Parameters and Histological Study of Spleen in the Wistar Rats Exposed To Cadmium Sulfate
}

\author{
Francis A.YAPO**1, Vandjiguiba DIABY ${ }^{1,2}$, Justin K.N'DAH ${ }^{3}$, \\ Mousan A.ADON ${ }^{2}$, Nazaire B.DJYH ${ }^{1}$, Mireille DOSSO ${ }^{5}$, JosephA.DJAMAN ${ }^{1,5}$ \\ ${ }^{1}$ Laboratory of Pharmacodynamics-Biochemical, UFR Biosciences, University FELIX HouphouëtBoigny- \\ Abidjan (Côte d'Ivoire), 22 Box 582 Abidjan 22. \\ ${ }^{2}$ Cellular unit of biology, Institute Pasteur (Côte d'Ivoire), 01 Box 490 Abidjan 01 \\ ${ }^{3}$ UFR of Medical Sciences, Laboratory of Anatomy and Pathological Cytology University Felix \\ HouphouëtBoigny-Abidjan (Côte d'Ivoire), 22 Box 582 Abidjan 22. \\ ${ }^{4}$ Department of Medical and Fundamental Biochemistry, Institute Pasteur (Côte d'Ivoire) 01 Box 490 Abidjan
}

\begin{abstract}
The pollution of the ecosystem by the industrial effluents and sewages has different consequences as air and food contamination with the toxic agents such are heavy metals. It constitutes a significant risk of public health.Six (6) batches of 5 males and females rats were made up. These rats were contaminated with various doses of cadmium sulfate $(0 ; 4 ; 5 ; 6,6,6 ; 10 ; 20 \mathrm{mg} / \mathrm{kg}$ of body weight) by daily during 30 days. At the end of the experiment, animals were sacrificed and their blood serum is used for the dosage of spleen biochemical parameters. Also, the spleens of these animals were extracted and weighed. After, they were placed in formalin (10\%) for histopathologic study by the technique of inclusion to paraffin.Cadmium sulfate reduced significantly the concentration of total bilirubin $(p<0,001)$ and the weight of the spleen $(p<0,05)$ without varying the concentration of total cholesterol. At the tissue level, the cadmium sulfate induced histological transformations characterized by iron deposit, veins dilatation, structural disorganization and edema in the contaminated rats.Cadmium sulfate caused a disturbance of splenic tissue in the rats.
\end{abstract}

Keywords: Cadmium sulfate, spleen, histopathology, biochemical parameters, weight

\section{Introduction}

Cadmium (Cd) is a strongly toxic heavy metal [1].It has an effect on all the body with a half-life between 15 to 30 years. The environmental exposure in the long time to $\mathrm{Cd}$ acts like a carcinogenic agent at the human ones [2,3].According to conditions' of exposure to metal (food or nicotine), $5 \%$ of introduced cadmium are absorbed by the gastro-intestinal tract in salt form, while $90 \%$ of inhaled cadmium are absorbed by pulmonary way [4]. The nicotine constitutes a significant cadmium contribution (approximately $1 \mu \mathrm{g}$ by cigarette) [5].

After ingestion, cadmium accumulates in the target bodies such are renal cortex and liver [5].The daily average contributions are approximately 10 to $35 \mu \mathrm{g}$ in the adult not smoker [5,6].These exposures to cadmium induce pathologies in various organsparticularly in the testicles, the brain, the nervous system [1] and in the liver, the kidney, spleen [7]. In adult, the spleen forms integral part of the lymphatic system and the vascular system.Its principal functions are immunizing defense by the manufacture of antibody starting from the plasmocytes[8]for the elimination of the micro-organisms coming from blood circulation [9].Also, the spleen takes part in the destruction of the old or abnormal blood cells, it extracts iron from haemoglobin contained in the red globules which it destroys and keeps it in reserve[10]. The spleen eliminates the biliary pigments. In certain mammals, the spleen stores the blood cells and reintroduces them in the circulatory system according to needs for kind to control blood volume in the event of hemorrhage [10]. However, the problems are that the toxicity of cadmium on the splenic function is not well elucidated [1]. Although the spleen is known for its essential role in the regulation of the immune system, its cytotoxicity induced by heavy metals remains less studied. Thus the objective of this study is to evaluate the bio-toxicity of splenic tissue in Wistar rats.

\section{Material}

\section{Material And Methods}

The biological material consists of rats male and female of Wistar stock weighing $106 \pm 6 \mathrm{~g}$ and old from 8 to 12 weeks.The rats were placed in cages and were acclimatized two weeks before the beginning of manipulation.They were nourished with pellets and were watered with the water of tap.The room was quite ventilated and enlightened 12 hour out of 24 .

The cadmium sulfate used for the tests was out of dehydrated salt of mark MERCK and whose job number is 1.02027.0100. 


\section{Methods}

\subsection{Preparation of the animals}

The animals were marked with the tail by batch inside each batch in order to identify them during the experimentation. Twelve (12) batches of five (5) rats were made up including 6 batches of males and 6 batches of females. Batch 1 (males) and batch 1 (females) constituted the control batches where the animals received distilled water by cramming ( $1 \mathrm{ml} / \mathrm{J}$ our). Batches $2,3,4,5$ and 6 of each sex received by cramming, each day respectively of $1 / 50^{\text {th }}, 1 / 40^{\text {th }}, 1 / 30^{\text {th }}, 1 / 20^{\text {th }}$ and $1 / 10^{\text {th }}$ of the $\operatorname{LD}_{50}(200 \mathrm{mg} / \mathrm{kg}$ of body weight (bw)) of the cadmium sulfate solution corresponding respectively to $4 ; 5 ; 6,66 ; 10$ and $20 \mathrm{mg} / \mathrm{kg} \mathrm{bw}$. The duration of treatment of the rats with cadmium sulfate was 30 Days [11]. The managed volume was of $1 \mathrm{ml}$ per day each morning throughout treatment.

\subsection{Blood collection, extraction of spleen and weighing}

After the period of exposure (30 Days) to cadmium sulfate, the rats were sacrificed. The Carotid blood of each rat was collected immediately in sample dry tube which was used to obtain the serum after centrifugation (3000 rpm/5min). This serum was used for the dosage of the spleen biochemical parameters with the automat Cobas (C311 ROCHE HITACHI) at the Pasteur Institute of Abidjan (Côte d'Ivoire). Then,the animals were placed on the back and a longitudinal dissection was made on the belly in order to extract the spleen which is weighed usingprecision balance and placed in formalin (10\%).

\subsection{Histopathological sections and observations}

The method used is the paraffin inclusion technique[12].Using a blade of lancet, longitudinal sections were carried out on withdrawn spleens of formalin, to take tissue parts. These parts are deposited in labelled perforated cassettes.

Fixing, dehydration, the explanation and the impregnation were made using an apparatus (Technicon ${ }^{\circledR}$ Tissue Tek) in which will circulate the cassettes and which will make remain the tissue parts in a series of reagents at times given to give them a mechanical resistance.Lastly, the parts contained in the cassettes were impregnated in two paraffin baths with $60^{\circ} \mathrm{C}$ during 30 minutes each one to increase the rigidity of splenic tissues. In order to facilitate the sections, the tissues impregnated were included in a block of paraffin. Then, using a microtome, mean sections of $3 \mu \mathrm{m}$ thickness were carried out on the blocks of paraffin containing the tissue parts. The tissues were spread out over the labelled blades out of glass then, they were dried with the drying oven with $37^{\circ} \mathrm{C}$ during one hour.Thesections dewaxed initially in a toluene bath, then hydrated in three baths of ethanol (of concentration respective $100^{\circ}, 95^{\circ}$ and $95^{\circ}$ ). And then, sections rinsed with water of tap, were colored with the hématoxyline during 5 minutes. The sections were rinsed with water before passing to eosine during three minutes. Finally the sections were dehydrated by making them pass successively in three alcohol baths $\left(95^{\circ}, 100^{\circ}\right.$ and $\left.95^{\circ}\right)$.

The section observation was made between blades and plates with the enlargement (Gx40) under binocular optical microscope (Olympus BX51, Japan) surmounted of a camera (Olympus DP 20-50, Japan).

\subsection{Statistical analyses of the data}

The software GraphPad.Prism.V5.01 was used for the statistical analysis of the results and the layout of the curves.The data were analyzed with ANOVA One-Way.The nonparametric Dunnett test was used for the comparison between the variance of the control and of the other results. The difference between two variances was significant if $p<0,05$.

\section{Effect of cadmium sulfate on spleen weight \\ 3.2. In male rats}

The figure 1 shows the impact of cadmium on the weight of spleen in the males. Cadmium induced a reduction proportions not-dependent on this organ at the treated batches. Indeed, compared to the control group $(320,66 \pm 13,43 \mathrm{mg})$, the weights of spleen of the treated batches decreased from $320,33 \pm 25,69 \mathrm{mg} / \mathrm{kg}$ for dose $4 \mathrm{mg} / \mathrm{kgbw}$ to $263,00 \pm 32,53 \mathrm{mg}$ for the high dose $(20 \mathrm{mg} / \mathrm{kg} \mathrm{bw})$. This weight reduction is significant $(\mathrm{p}<0,05)$ for the doses of $6,66 \mathrm{mg} / \mathrm{kgbw}(256,33 \pm 18,77 \mathrm{mg})$ and $20 \mathrm{mg} / \mathrm{kg}$ bw $(263,00 \pm 32,53 \mathrm{mg})$ (Fig 1).

\subsection{In female rats}

The figure 2 shows that the effect of cadmium on the weight of spleen in animal females is characterized by a reduction. The decreasing of the weight of this organ in female is not doses dependent. Compared to the control group $(326,2 \pm 18,43 \mathrm{mg})$, the weights of spleen of the treated batches decreased from $306 \pm 15,80 \mathrm{mg}$ for the doseof $4 \mathrm{mg} / \mathrm{kgbw}$ to $258,8 \pm 38,42 \mathrm{mg}$ for the high dose $(20 \mathrm{mg} / \mathrm{kgbw})$. This reduction is significant $(\mathrm{p}<0,05)$ for the doses of 6,66 and $20 \mathrm{mg} / \mathrm{kgbw}($ Fig 2). 


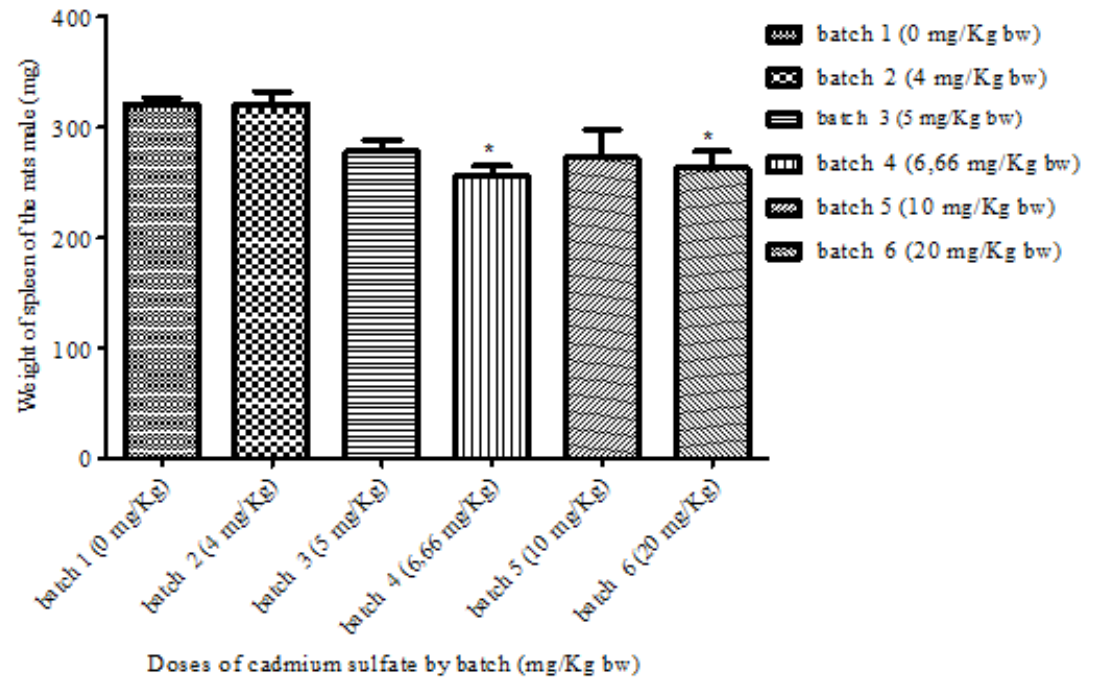

Fig 1: Effect of cadmium sulfate on the weight of spleen in the male rats Significance level: $*=\mathrm{p}<0.05$ with $\mathrm{n}=5$

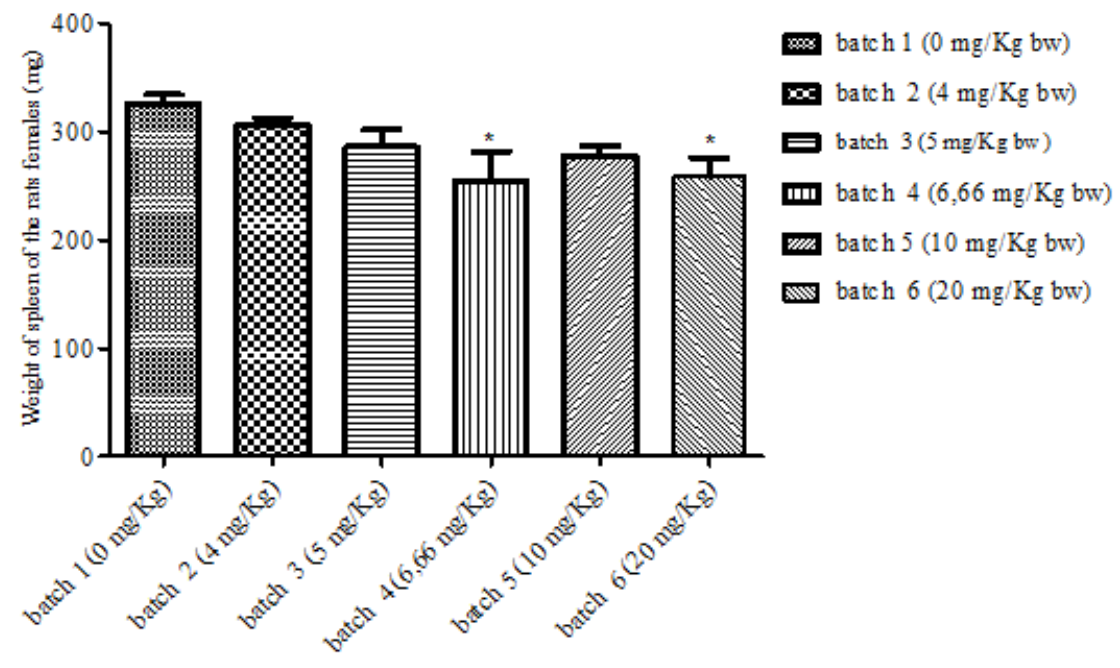

Doses of cadmium sulfate by batch ( $\mathrm{mg} / \mathrm{Kg}$ bw)

Fig 2: Effect of cadmium sulfate on the weight of spleen in the female rats Significance level: $*=p<0.05$ with $n=5$

\section{Action of cadmium sulfate on the spleen biochemical parameters}

\subsection{Action of cadmium sulfate on total bilirubin}

The rate of total bilirubin was decreased significantly for all the test concentrations $(4 ; 5 ; 6.66 ; 10$ and $20 \mathrm{mg} / \mathrm{kg} \mathrm{bw})$ both in the male rats $(1.35 \pm 0.7 \mathrm{~g} / \mathrm{L} ; \mathrm{p}<0.0001 ; 1.60 \pm 0.31 \mathrm{~g} / \mathrm{L} ; \mathrm{p}<0.001 ; 1.76 \pm 0.27 \mathrm{~g} / \mathrm{L} ; \mathrm{p}<0.0001$ and $0.21 \pm 0.09 \mathrm{~g} / \mathrm{L} ; \mathrm{p}<0.0001)$ than in females compared to the control rats groups (male: $2.43 \pm 0.68 \mathrm{~g} / \mathrm{L}$ and female:1.62 $\pm 0.26 \mathrm{~g} / \mathrm{L}$ ) (table I). This reduction is dose-dependent in the male rats (table I).

\subsection{Action of cadmium sulfate on total cholesterol}

For total cholesterol, table I shows nonsignificant variation both in the two sex, although some concentrations of cadmium induced augmentation or reduction of the cholesterol rate. The total cholesterol rates varied serratedboth in the two sex compared to the control groups (Table I).

Table I: Effect of cadmium on spleen biochemical markers in rat

\begin{tabular}{|c|c|c|c|c|c|}
\hline & & \multicolumn{4}{|l|}{ parameters } \\
\hline & & \multicolumn{2}{|l|}{ males } & \multicolumn{2}{|l|}{ Females } \\
\hline Batches & $\begin{array}{l}\text { Concentrations } \\
(\mathbf{m g} / \mathbf{K g ~ b w})\end{array}$ & Bilirubin $(\mathrm{g} / \mathrm{L})$ & Cholesterol (g/L) & Bilirubin $(\mathrm{g} / \mathrm{L})$ & Cholesterol (g/L) \\
\hline Lot 1 (control group) & $\mathbf{0}$ & $2.43 \pm 0.68$ & $0.94 \pm 0.06$ & $1.62 \pm 0.26$ & $0.66 \pm 0.10$ \\
\hline Lot 2 & 4 & $1.35 \pm 0.7 * * *$ & $0.96 \pm 0.22$ & $0.99 \pm 0.13$ *** & $0.72 \pm 0.13$ \\
\hline
\end{tabular}


Assessment Of Biochemical Parameters And Histological Study Of Spleen In The Wistar Rats...

\begin{tabular}{|l|l|l|l|l|l|}
\hline Lot 3 & $\mathbf{5}$ & $1.60 \pm 0.31^{* *}$ & $0.72 \pm 0.09$ & $1.08 \pm 0.08 * *$ & $0.85 \pm 0.33$ \\
\hline Lot 4 & $\mathbf{6 . 6 6}$ & $1.76 \pm 0.27^{*}$ & $0.88 \pm 0.06$ & $1.09 \pm 0.09 * *$ & $0.63 \pm 0.09$ \\
\hline Lot 5 & $\mathbf{1 0}$ & $1.46 \pm 0.29^{* * *}$ & $0.91 \pm 0.22$ & $1.14 \pm 0.01 * *$ & $0.73 \pm 0.17$ \\
\hline Lot 6 & $\mathbf{2 0}$ & $0.21 \pm 0.09 * * *$ & $0.97 \pm 0.38$ & $1.16 \pm 0.41 *$ & $0.54 \pm 0.11$ \\
\hline
\end{tabular}

Significance level:It* $=\mathrm{p}<0.05 ; \mathbb{T}^{* *}=\mathrm{p}<0.001 ; \mathbb{T}^{* * *}=\mathrm{p}<0.0001$ with $\mathrm{n}=5$

\section{Tissue toxicity of spleen induced by cadmium sulfate in the rats wistars}

5.2. In male rats

The figures3A1 to3A6 show the effect of cadmium sulfate on splenic tissue in the males. At the control group (Fig 3A1), the architecture of spleen was normal.Indeed, white pulp, red pulp and the marginal zone were visible.However, the treated rats saw the splenic architecture modification according to cadmium sulfate doses. With the dose of $4 \mathrm{mg} / \mathrm{kgbw}$ (Fig3A2), the splenic architecture was little modified with a white pulp and a red pulp not very distinct.These same observations were made atdose $5 \mathrm{mg} / \mathrm{kgbw}$ with iron deposits (Fig 3A3).At $6,66 \mathrm{mg} / \mathrm{kgbw}$, the splenic artery was discreetly modified. This discreetly disorganized marginal zone and the capillaries as well as the venous sine was dilated.About this same dose $(6,66 \mathrm{mg} / \mathrm{kgbw})$, there was appearance of an arterial thrombosis (Fig 3A4).With the dose of $10 \mathrm{mg} / \mathrm{kg}$, the capillaries were dilated accompanied by congestion and architectural disorganization as well as dilation of the venous sine (Fig 3A5).for $20 \mathrm{mg} / \mathrm{kg}$, it caused a structural disorganization with appearance of edema and a endothelite as well as a thrombosis of the splenic artery(Fig 3A6).

\subsection{In female rats}

The figures 4B1 to 4B6 translate the effect of cadmium sulfate on splenic tissue in the female rats. At the control group (Figure 4B1), the architecture of splenic tissue remained intact withthe white pulp, the red pulp and the marginal zone were visible. With regard to the treated rats, the toxic effect of cadmium is quite visible and varies according to the doses. With the dose of $4 \mathrm{mg} / \mathrm{kgbw}$, an architectural modification was observed (Fig 4B2). This modification is also visible with $5 \mathrm{mg} / \mathrm{kgbw}$ with vascular congestion followed by iron deposit (Fig 4B3). As for the dose 6,66 mg/kgbw, the splenic artery was little modified (Fig 4B4). With the dose $10 \mathrm{mg} / \mathrm{kg}$ bw (Fig 4B5), it was observed iron deposits, architectural disorganizations, a congestion and a hemorrhage.Concerning the highdose $(20 \mathrm{mg} / \mathrm{kgbw})$, a strong architectural disorganization was noticed with vein dilation (Fig 4B6).

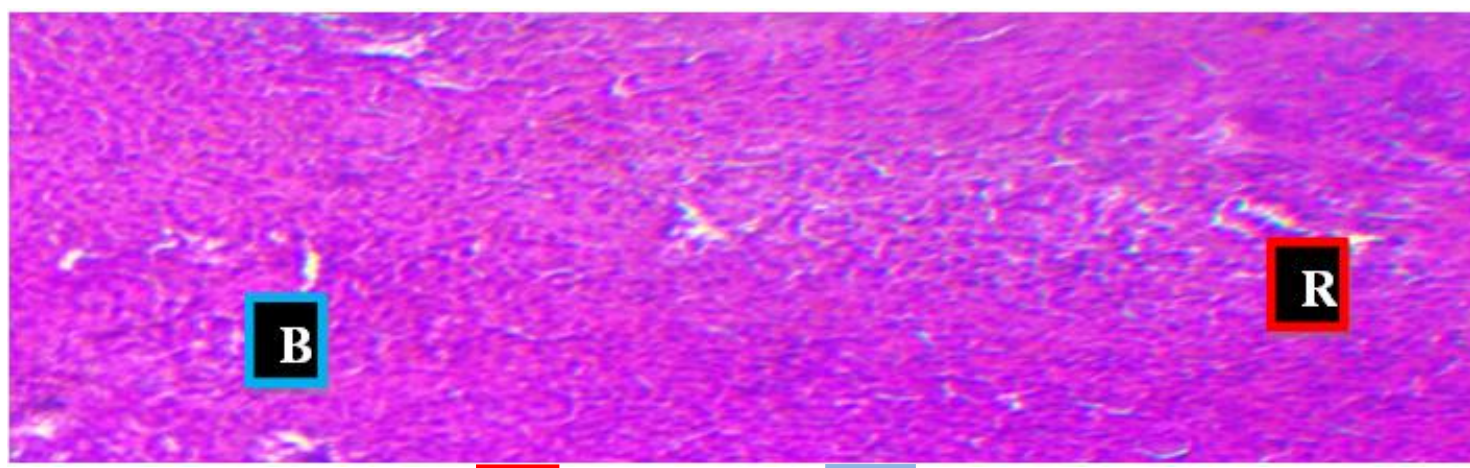

Fig 3A1/HEx10: Pulp red $\quad$ R ) and pulps white ( $\mathbf{B}$ ) dictincts (normal Architecture)

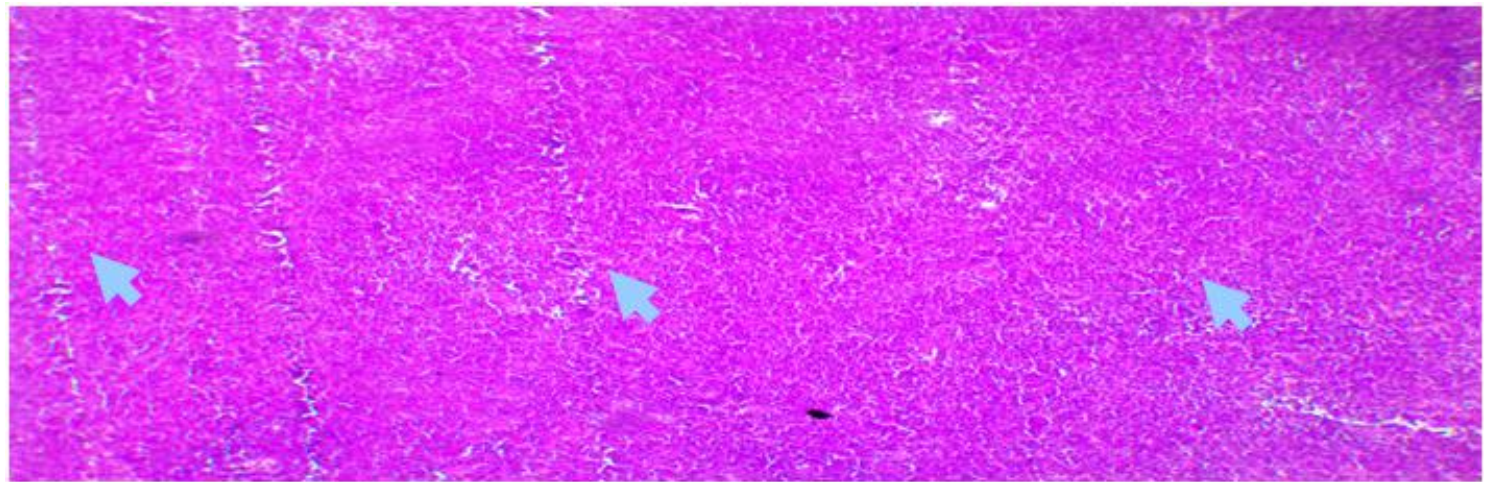

Fig 3A2/HE x 10: structure little modified ( $)$ 


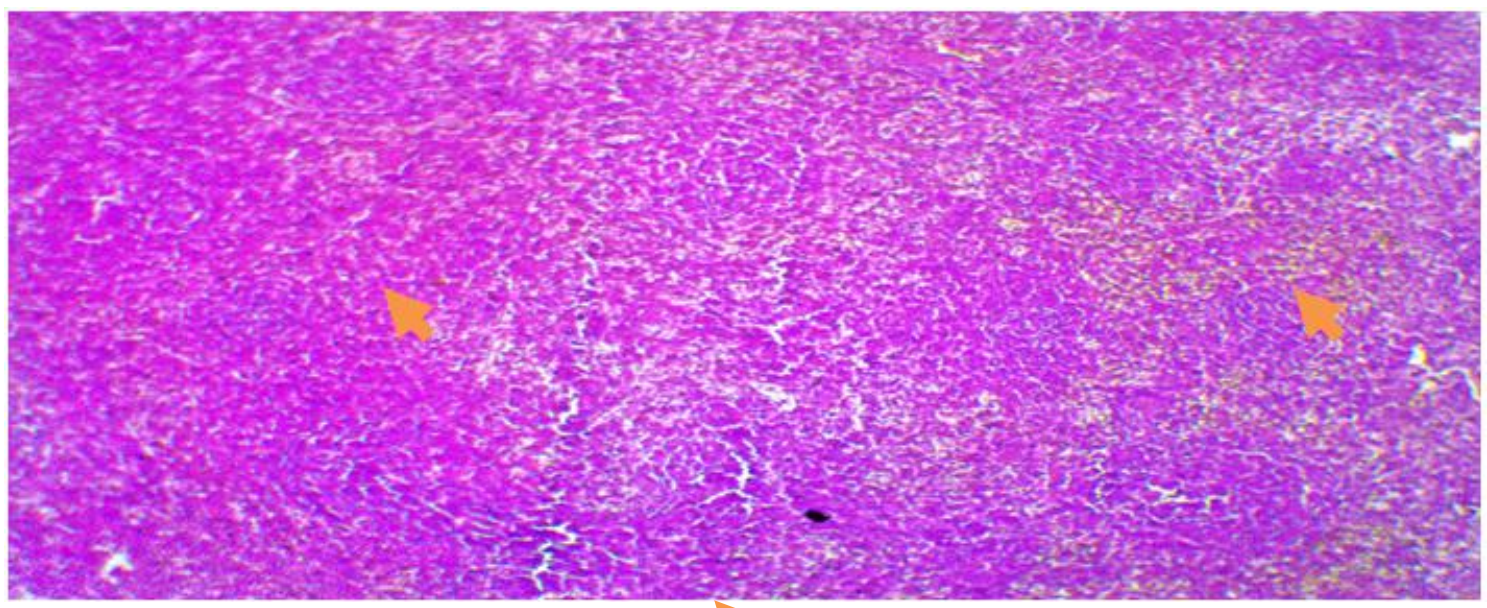

Fig 3A3/HE x 10: Iron deposits ( $)$ and modification of architecture

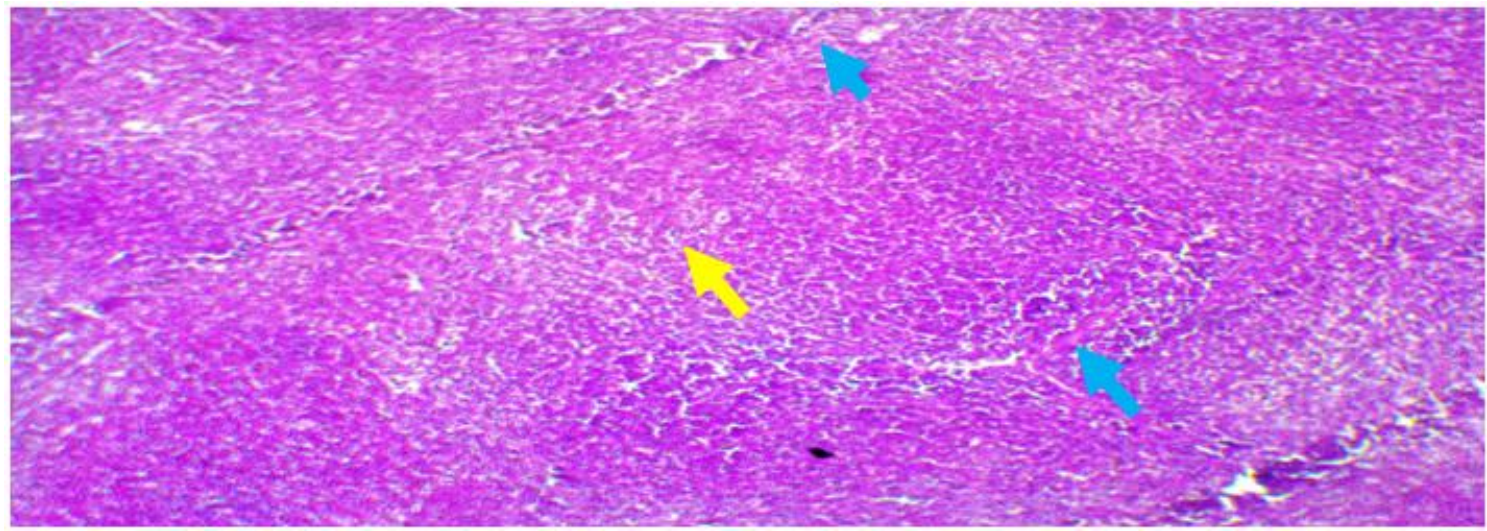

Fig 3A4 /HE x 10: Splenic arteries discreetly modified (

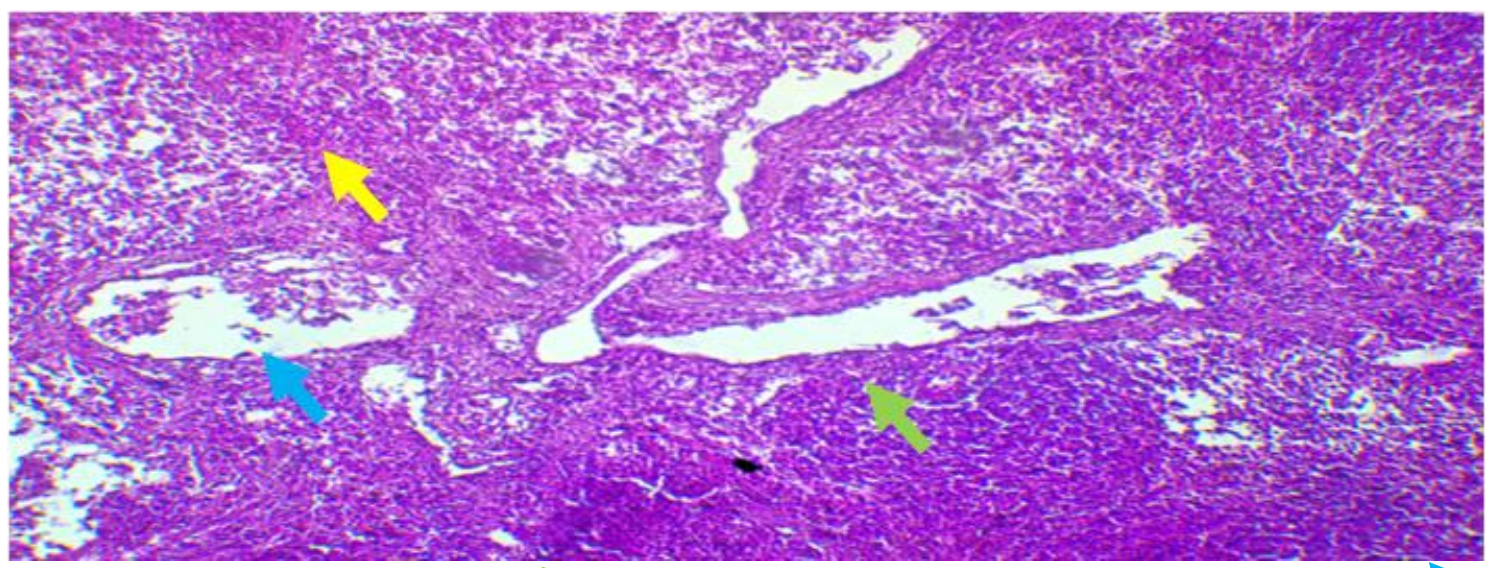

Fig 3A5/ HE x 25: dilated capillary $(\checkmark)$, vascular congestion ( ), dilation of the venous sine ( 


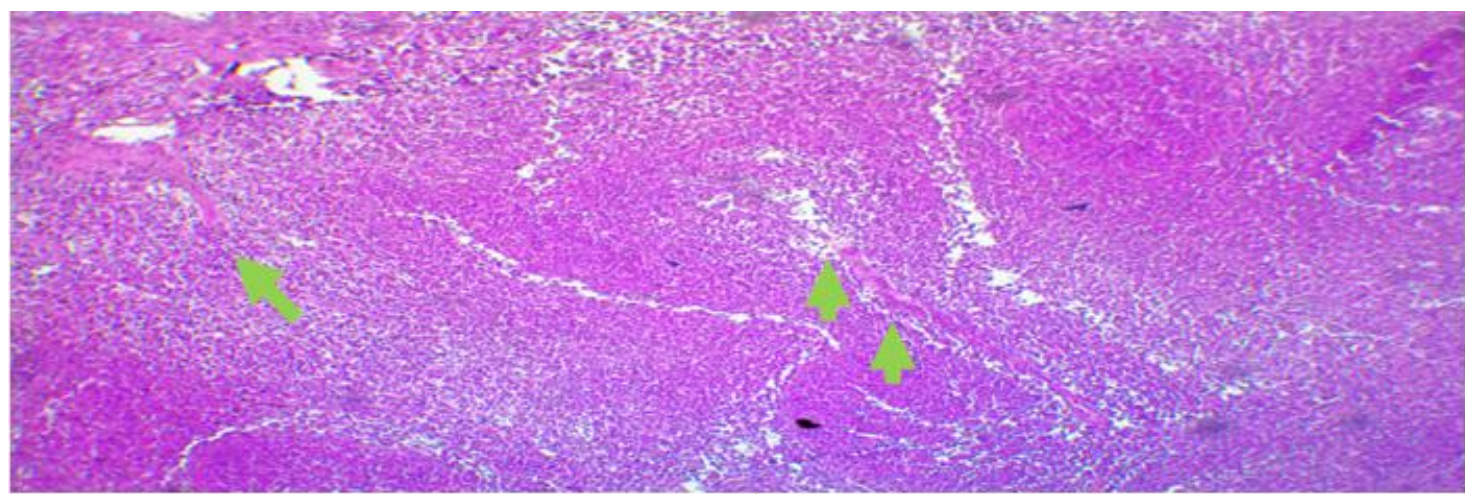

Fig 3A6/ HE x 10: Structural disorganization, oedema ), endothelite and a thrombosis of the splenic artery Fig 3A: Tissue toxicity of cadmium sulfate on spleen in the male rats $(\mathrm{Gx} 10)$

A1 :Control group $(0 \mathrm{mg} / \mathrm{kg} \mathrm{bw})$

A2 : with the dose of $4 \mathrm{mg} / \mathrm{kg}$ bw A3 : with the dose of $5 \mathrm{mg} / \mathrm{kg}$ bw
A4 : with the dose of $6,66 \mathrm{mg} / \mathrm{kg}$ bw

A5 : with the dose of $10 \mathrm{mg} / \mathrm{kg}$ bw A6 : with the dose of $20 \mathrm{mg} / \mathrm{kgbw}$

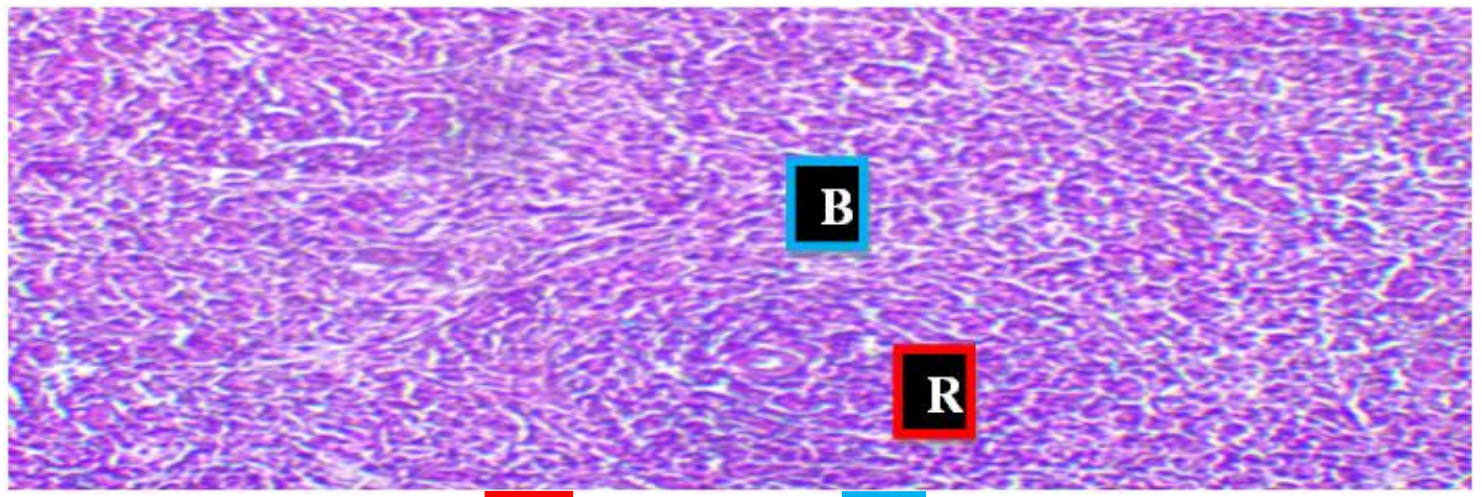

Fig 4B1/HE x 10: Pulp red $\mathbf{R}$ ) and pulps white

\section{B}

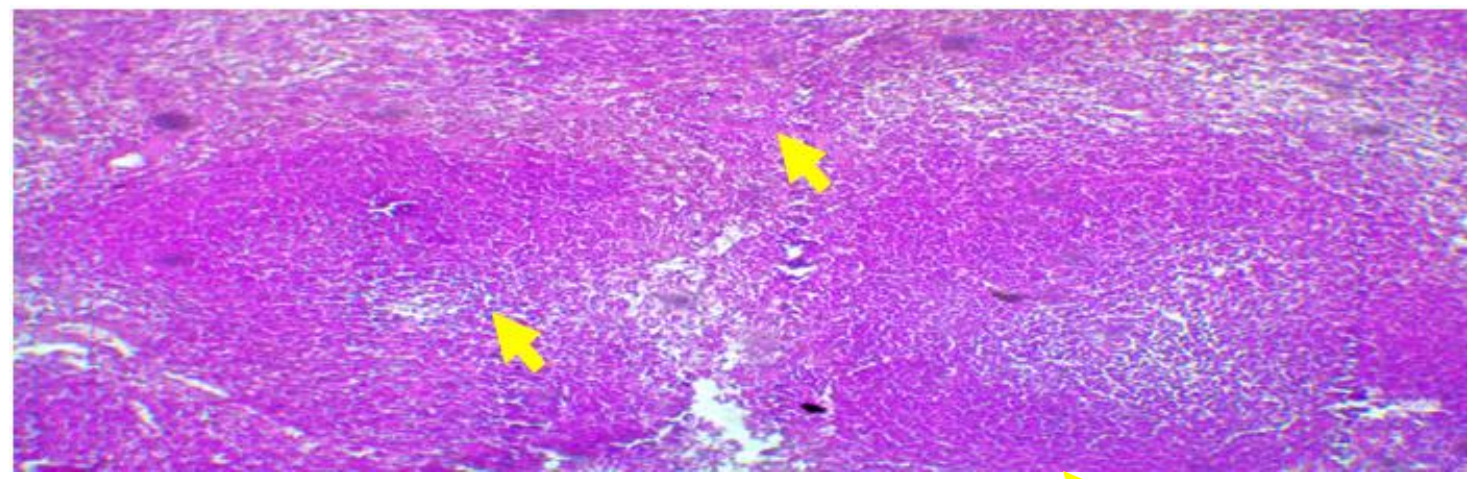

Fig 4B2/HE x 10: architectural disorganization ( 


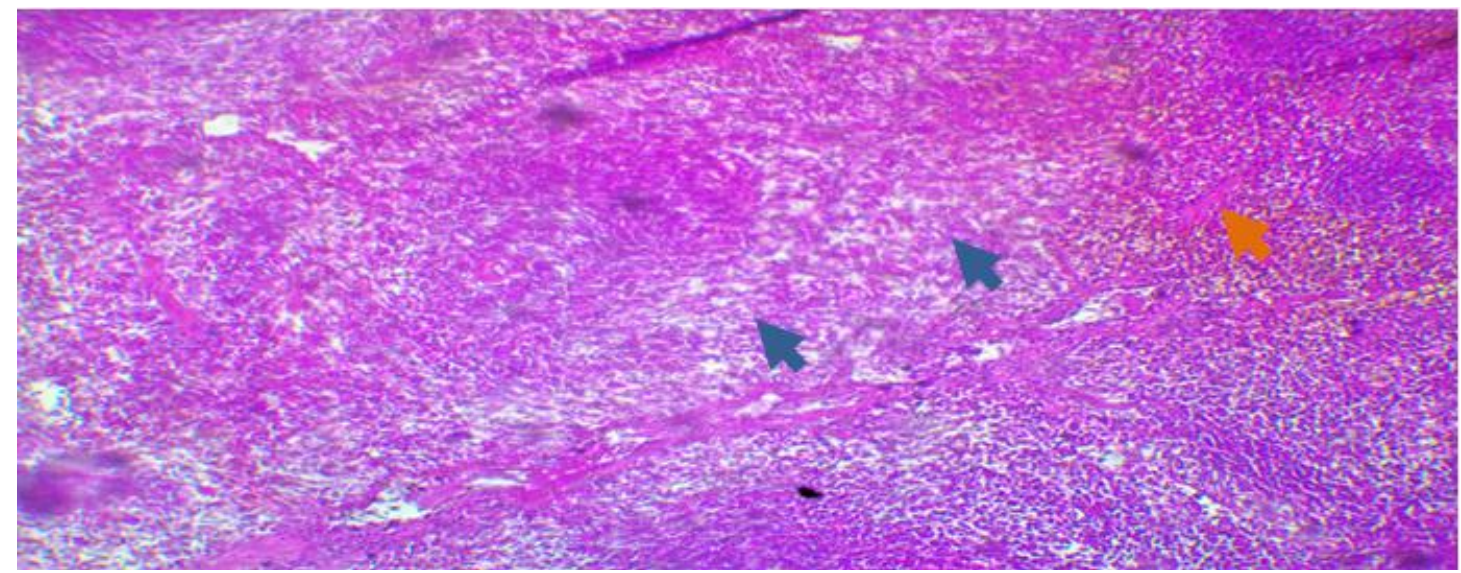

Fig 4B3/HE x 10:Architectural modifiaction ( $)$, vascular congestion andiron depot (

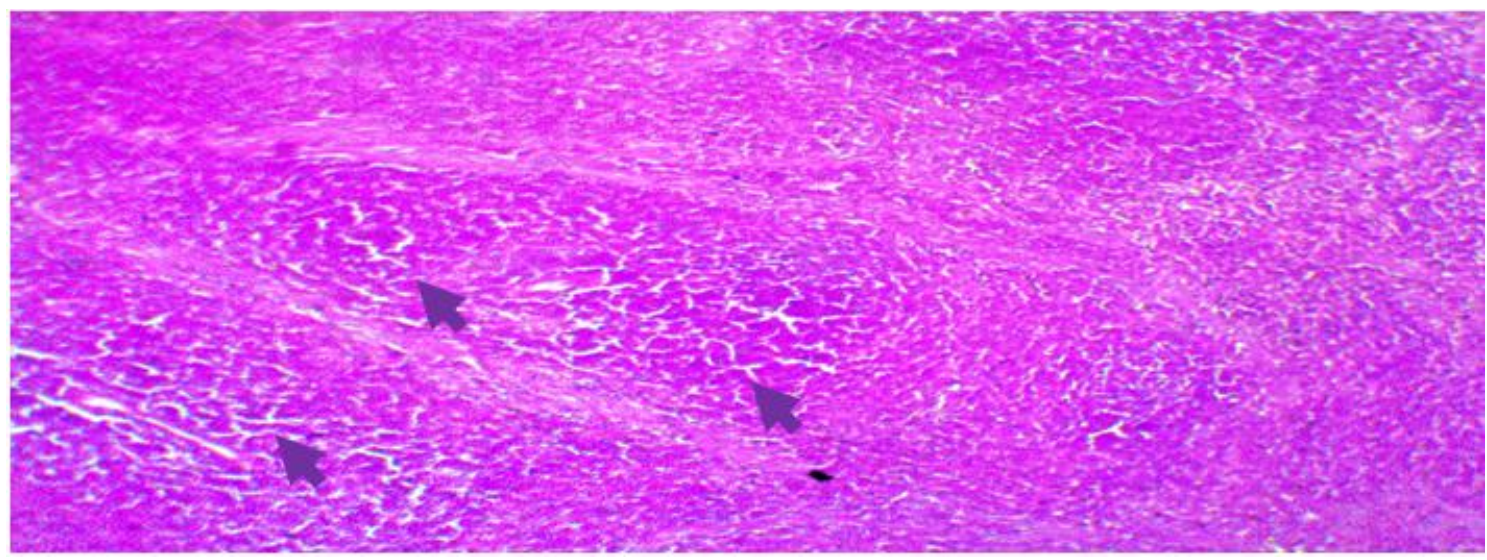

Fig 4B4/HE x 10: Structure little modified (

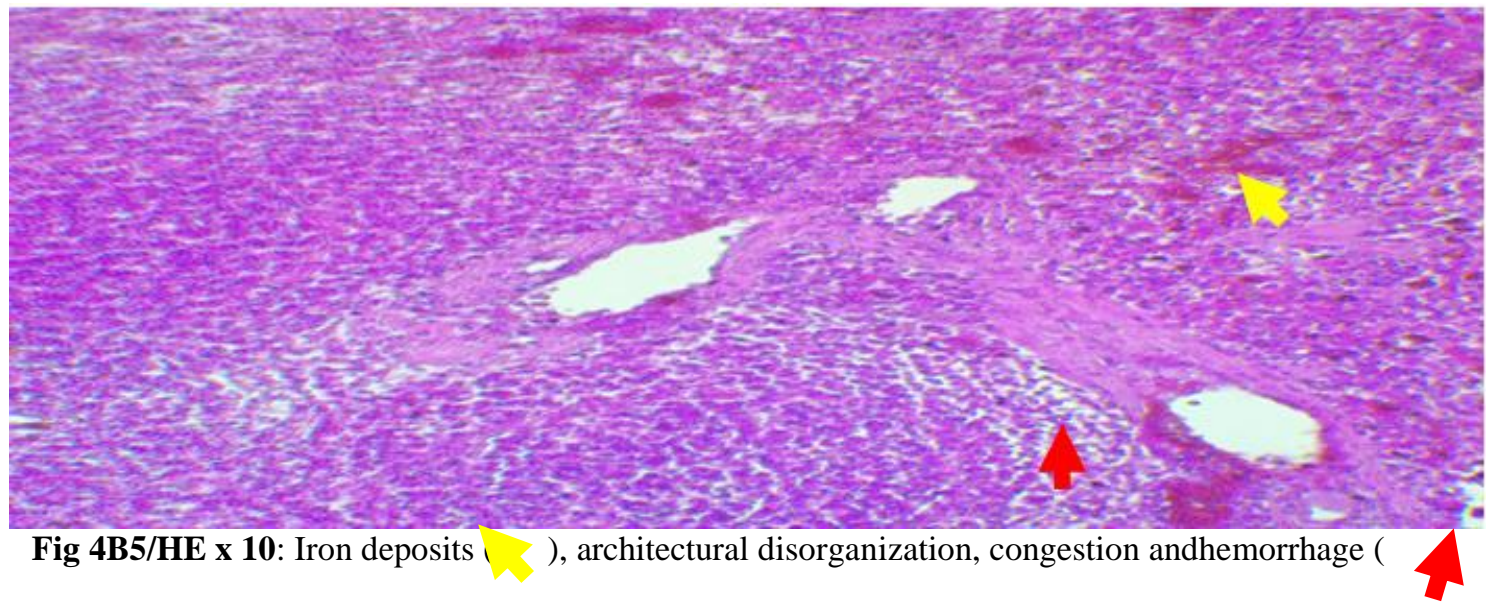




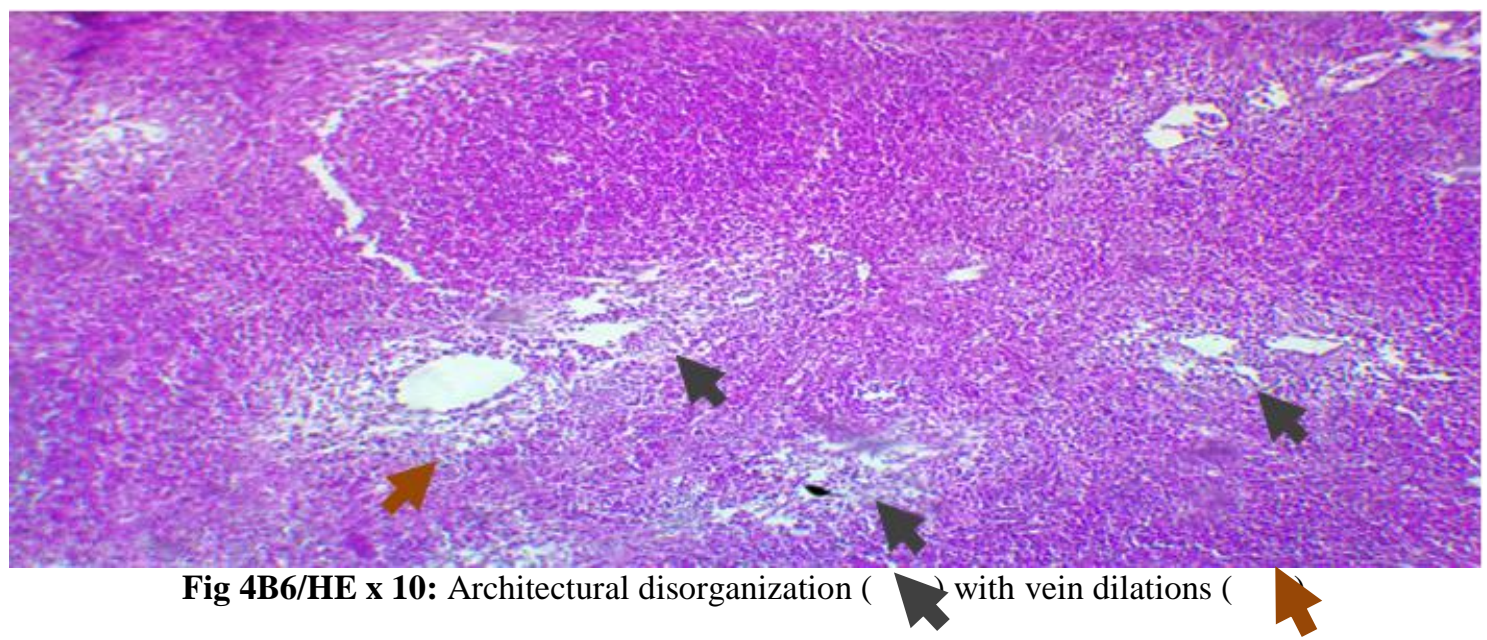

Fig 4B: Tissue toxicity of cadmium sulfate on spleen in the female rats $(\mathrm{Gx} 10)$

B1: at the control group $(0 \mathrm{mg} / \mathrm{kg} \mathrm{bw})$

B2: with the dose of $4 \mathrm{mg} / \mathrm{kg}$ bw

B4: with the doseof $6,66 \mathrm{mg} / \mathrm{kg}$ bw

B5: with the dose of $10 \mathrm{mg} / \mathrm{kg}$ bw

B3: with the dose of $5 \mathrm{mg} / \mathrm{kg}$ bw

B6: with the dose of $20 \mathrm{mg} / \mathrm{kgbw}$

\section{Discussion}

The results of loss of weights noted at the time of the study are in agreements with those of Šimonytee $e$ al., [13] where the mice were watered with water enriched with cadmium chloride $(10 \mathrm{mg} / \mathrm{L})$ during 8 weeks. Losses of weight, weaknesses and mortalities were noted. Indeed, Already with $0.15 \mathrm{mg} / \mathrm{kg}$ cadmium sulfate considered as proportions pathological at the time of the study of Berroukcheet al.. [14]showed a similar loss of weight where the weakest concentration was $4 \mathrm{mg} / \mathrm{kg}$ body weight.

The biochemical parameters make it possible to evaluate possible toxic effects of an agent on the physiological functions of the organism responsible for many diseases [15]. The bilirubin is the breakdown product of red blood corpuscles out-of-date or damage. These red blood corpuscles will release heme and the globine[16]. In the liver, bilirubin binds to other molecules before being excreted in the bile. The results obtained showed a significant reduction in the bilirubin compared to the control group in both rats sexes. These results confirmed the total correlation between bilirubin and cadmium where Zeneliet al., [17] noted that the high cadmium concentration in blood is due to cigarette smoke. In fact, this cadmium inhibits the synthesis of bilirubin. The bilirubin rate reduction in blood may be caused by anemia [17] due to cadmium.

The toxicity effects vary according to the intensity, the way, the frequency and the exposure time but also the species, of the sex, the age and the health of the exposed populations [18].The accumulation thus of cadmium in the organism has a significant incidence concerning its chronic toxicity, its cancerogenic effects [15] and its damage on various tissues[19]. In the guinea-pigs, the toxicity of lead acetate and cadmium chloride on the histopathological parameters was studied by Randaet al., [20] and it arises that these metals damage mainly the kidneys and the liver.However, renal dysfunction[7] affects other organs mainly the spleen which intervenes in the immunological function [21].The spleen is a significant organ of the circulatory immune system and gives significant interpretation concerning the toxicity of the substance entering the body [22]. The results obtained showed as well as in the male rats as female, cadmium sulfate has affected the splenic structural architecture of the contaminated rats characterized by an iron deposit, a venous sine, a congestion, a hemorrhage, a structural disorganization and an edema in the exposed rats. These results are similar to the work ofHamak and Thalij, [21] on the histological transformation of rate caused by cadmium and copper at thedoses of $0.0025 \mu \mathrm{g} \mathrm{Cd} / \mathrm{animal} / \mathrm{day}$ and $0.005 \mu \mathrm{g} \mathrm{Cu} / \mathrm{animal} /$ day. A moderate dose of $\mathrm{Cd}(15 \mathrm{mg} / \mathrm{L})$ is sufficient to generate proliferative lesions and hearths of neoplasy on various tissues in the Wistarrat noted byBerroukcheet al., [15]. Other studies have showed, in the rats exposed to $\mathrm{Cd}$ in the presence of zinc, cellular disorganizations, cyto-nuclear atypies and necrosis on the level of hepatic and renal tissuesBerroukcheet al., [14].Also, at Tilapia exposed to cadmium, Piraratet al., [1] haveobserved in spleen, anenlargement of the ellipsoidal tissue, the aggregation of melano-macrophage cells, the vacuolar degeneration and the capillaryoedematosis. The results of our work about the high doses corroborate those ofDavid and Kartheek,[8]who have noted in fish exposed to sodium cyanide, an iron deposit which could be explained by a strong destruction of the erythrocytes in spleen. On the kidneys, Kaplan et al., [23] showed that cadmium has affected particularly the proximal tubule tissues in the treatment of the cadmium intoxications. 


\section{Conclusion}

This work showed that the cadmium sulfate induced a reduction proportions not-dependent on the weight of spleen in the rats whatever the sex.Also, it induced a disturbance of the splenic function in the rat due to the variation of the rate of total bilirubin. This is translated at the tissue level by its damage in the contaminated rats characterized by congestion, a deposit of iron, an edema and a structural disorganization. These pathologies of rate could be the risks incurred by the exposed human populations in a chronic way to cadmium.

\section{Acknowledgements}

Authors are grateful to the leaders of Pasteur Institute units and its General Director. We thank the Department ofMedicaland FundamentalBiochemistry for the biological tests. We also grateful the Department of SVT of High Normal School of Côte d'Ivoire for his pet shop and the various experiments on wistar rats.

\section{References}

[1]. N. Pirarat, P. Chotipong, P. Singhasenee, Toxicity of Cadmium on Tilapia (Oreochromisniloticus) Spleen: Proc. 15th Congress of Federation of Asian Veterinary Association, 2008, 143-144.

[2]. W.E. Achanzar, B.A. Diwan, J. Liu, S.T. Quader, M.M. Webber, M.P. Waalkes, Cadmium-induced malignant transformation of human prostate epithelial cells, Cancer Research, 61(2), 2001, 455-458.

[3]. J. Luevano and C. Damodaran,A Review of Molecular Events of Cadmium-Induced Carcinogenesis, Journal Environmental Pathology, Toxicology and Oncology, 33(3), 2014, 183-194.

[4]. L. Jarup,Cadmium overload and toxicity, Nephrology Dialysis Transplantation, 17(Suppl 2), 2002, 35-39.

[5]. P. Andujar, L. Bensefa-Colas, A. Descatha, Acute and chronic cadmium poisoning. Revue de Médecine Interne, 31 (2), 2010, 107-15.

[6]. M.K. Koffi, Y. Ake-Assi, J. S. SAKI, H. M. G. A. BIEGO,Evaluation de l'exposition de la population aux métaux traces (cadmium, mercure, plomb) à travers la consommation des viandes et abats de bœuf et de porc importés, International Journal of Biological and Chemical Sciences, 8(4), 2014, 1594-1603.

[7]. V. Diaby, F.A.Yapo, A.M. Adon, M. Dosso, J.A. Djaman, Renal, hepatic and splenic biotoxicity of cadmium sulphate in the Wistar rats,International Journal of Environmental Science and Toxicology Research, 4(6), 2016, 103-110.

[8]. M. David and R.M. Kartheek, Histopathological alterations in spleen of freshwater fish Cyprinuscarpio exposed to sublethalconcentration of sodium cyanide, Open Veterinary Journal, 5(1), 2015, 1-5.

[9]. R.E. Mebius and G. Kraal, Structure and function of the spleen, Nature Reviews Immunology 5, 2005 , 606-616.

[10]. K. Hirazono, T. Shinozuka, Y. Kuroshima, H. Itoh, K. Kawai, Immunohistochemical expression of gluthatione S-transferase and chemotherapy response in malignant ovarian tumors, Journal of ObstetricsandGynaecology, 21, 1995, 305-312.

[11]. N. Layachi and Z. Kechrid,Combined protective effect of vitamins C and $E$ on cadmium induced oxidative liver injury in rats. African Journal of Biotechnology, 11(93), 2013, 16013-16020.

[12]. R. Hould,Technique d'histopathologie et de cytopathologie (Maloine édition, Paris, France, 1984).

[13]. S. Šimonytė, G. Čerkašin, R. Plančiūnienè, R. Naginienè, S. Ryselis, L. Ivanov, Influence of cadmium and zinc on the mice resistance to Listeria monocytogenes infection, Medicina, 39, 2003, 767-772.

[14]. A. Berroukche, M. Slimani, K. Kahloula, H. Kafi and A. Cheikh, Evaluation de l'activité du cadmium, en présence du zinc, sur les structures des tissus régulateurs du métabolisme chez le rat Wistar, International Journal of Biological and Chemical Sciences, 8(4), 2014, 1796-1807.

[15]. M. Smaoui, G. Fatma, B. Manel, M.-A. Fatma, E.F. Abdelfattah, Impact de l'exposition chronique aux gaz d'échappement d'origine automobile sur certains biomarqueurs touchant la fonction hormonale sexuelle mâle, la fonction rénale et l'hémogramme chez le rat, Pollution Atmosphérique, 167, 2000, 439449.

[16]. T. Basso, C. Fabris, M. Plebani, G. Del Faveroand M. Muraca,Alterations in bilirubin metabolism during extra-and intrahepatic cholestasis, Journal of Molecular Medicine, 70, 1991, 1432-1440.

[17]. L. Zeneli, H. Paçarizi, N.M. Daci, M. Daci-Ajvazi and A. Prenaj, The Effects of Air Pollution and Smoking on Cadmium Concentration in Human Blood and Correlation with Biochemical Parameters, American Journal of Biochemistry \& Biotechnology , 5 (2), 2009, 59-62.

[18]. M.C.F. Moussavou, Etude des mécanismes d'accumulation du cadmium chez Arabidopsisthaliana (écotype Wassilewskija) et chez un mélèze hybride (Larix x eurolepis) par des approches moléculaire et développementale, doctorat de l'Université de Sciences pour l'Environnement / Biologie - Science Santé de Limoges, France, 2010.

[19]. E. Fernandez, A. Gustafson, M. Anderson, B. Hellman, L. Dencker, Cadmium induced changes in apoptic gene expression blocked by zinc supplementation, Toxicological Sciences, 10, 2003, 85-99. 
[20]. A.H. Randa, M.A. Dawlat, A.R. Nariman, M.E. Hatem and M.I. Dessouky, Clinicopathological, histopathological and immunological studies on animals exposed to lead and cadmium under experimental conditions, New York Science Journal, 5(12), 2012, 120-136.

[21]. M. L. Hamak and K. M. Thalij, Estimation of Cadmium and Cupper in Some Foods and Drinking Water in Iraqi Markets and Illustrated the Ultra Structural Alterations of its Ranged in Rats Spleen, International Journal of Current Microbiology and Applied Sciences, 4(3), 2015, 174-181.

[22]. K. Dwivedi, Study of effect of cadmium and arsenic toxicity on organs weight in relation to body weight, Indian Journal of Science Research and Technology, 3(4), 2015, 6-13.

[23]. M. Kaplan, İ. H.Atakan, N.Aydoğdu, T.Aktoz, F. Ö.Puyan, G.Şeren, B.Tokuç, O.İnci, The effect of melatonin on cadmium-induced renal injury in chronically exposed rats,Turkish Journal of Urology, 35(2), 2009, 139-147. 